\title{
O DIREITO FUNDAMENTAL AO PLANEJAMENTO FAMILIAR E A NECESSIDADE DE REGULAMENTAÇÃO DA REPRODUÇÃ̃O HUMANA ASSISTIDA ${ }^{1}$
}

THE FUNDAMENTAL RIGHT TO FAMILY PLANNING AND THE NEED TO REGULATE ASSISTED HUMAN REPRODUCTION

João Vítor Lopes AMORIM²

Lislene Ledier AYLON ${ }^{3}$

ISSUE DOI: $10.21207 / 2675-0104.2018 .722$

\section{RESUMO}

Os direitos fundamentais da pessoa humana são reconhecidos e garantidos pela Constituição Federal de 1988. Dentre eles, encontra-se o planejamento familiar, determinado no artigo $226, \S 7^{\circ}$ da Carta

\footnotetext{
${ }^{1} \mathrm{O}$ presente artigo sintetiza a monografia de conclusão da pesquisa, realizada para o Programa Interno de Bolsas de Iniciação Científica (PIBIC 2017-2018) da Faculdade de Direito de Franca (FDF), Franca/SP.

${ }^{2}$ Discente da Faculdade de Direito de Franca (FDF), Franca/SP. Bolsista do Programa Interno de Iniciação Científica (PIBIC 2017-2018).

${ }^{3}$ Doutoranda no programa de Doutorado em Direito, da FADISP (Faculdade Autônoma de Direito) em São Paulo/SP, tendo concluído os créditos em dezembro de 2017. Mestre em Direito Privado pela Universidade de Franca (2002). Pós Graduada em Direito Penal e Processual Penal pela Faculdade de Direito de Franca (1995).Graduada em Direito pela Universidade Estadual Paulista Júlio de Mesquita Filho (1989), Foi professora de Direito Civil na UNIFRAN (Universidade de Franca) de1999 a 2005, na UNIP (Universidade Paulista), campus de Santos/SP de 2013 a 2016 e na UNAERP (Universidade de Ribeirão Preto), campus Guarujá/SP, de 2014 a 2016. Atuou como avaliadora em bancas de defesa de monografias em cursos de Pós-Graduaçao lato sensu da UNOPAR (universidade do Norte do Paraná em 2016 e 2017. Atualmente é professora na Faculdade de Direito de Franca/SP, da disciplina Direito Civil III (Contratos) e coordenadora do Núcleo de Assistência Judiciária da Faculdade de Direito de Franca.
} 
Maior. O referido direito é estabelecido como livre escolha do casal, obrigando-se o Estado a propiciar os meios médicos e educacionais para que possa ser exercido, proibidas as práticas impeditivas por parte do poder público ou privado e suas respectivas instituições. Isto posto, como pode se comportar o planejamento familiar em vista do empecilho reprodutivo, nos casos de esterilidade ou infertilidade do casal? Com o grande aumento da busca das técnicas de reprodução assistida no território brasileiro devido à sua popularidade atual, não restam dúvidas de que questões jurídicas importantes são levantadas a todo momento. No entanto, em virtude da ausência de legislação sobre o assunto, a resolução desses conflitos torna-se complexa. Este artigo, portanto, tem o intuito de compreender os principais aspectos jurídicos do emprego das técnicas de reprodução assistida, recorridas quando há impossibilidade ou dificuldade do casal em procriar, visto que a ausência de uma regulamentação específica permite várias lacunas e interpretações.

Palavras-chave: Direito fundamental. Planejamento familiar. Reprodução humana assistida. Regulamentação.

\begin{abstract}
The human fundamental rights are acknowledged and granted by the 1988 Brazilian Federal Constitution. Amongst them, the right to family planning is found, stated on the Article $226, \$ 7^{\circ}$ of the Constitution. Such right is known for its free will provided to the couple, along with the mandatory for the State to provide the educational and scientific resources for it exercise, forbidden any coercion made by public or private institutions. That stated, how can the family planning be fulfilled when the couple is diagnosed with sterility and infertility? With the increased search for the reproductive procedures justified by its current popularity, there are no doubts that relevant legal issues arise frequently. However, due to the lack of legislation on the matter, solving its conflicts becomes a complex task. Therefore, this article intendeds to understand the main legal aspects surrounding the assisted reproduction techniques, once the lack of regulation allows many legal gaps and interpretations.
\end{abstract}

Keywords: Fundamental right. Family planning. Assisted human reproduction. Regulation.

INTRODUÇÃO

Determinou-se na Conferência Mundial de População, ocorrida em Bucareste no ano de 1974, a existência do direito inerente a todo ser humano de receber do Poder Público informações sobre as possibilidade do planejamento familiar livre e eficaz ${ }^{4}$, de modo que, como expõe Maria Helena Diniz, deva existir a possibilidade "de obter gratuitamente os meios indispensáveis para a efetivação das decisões tomadas conscientemente pelo casal em matéria de procriação"5.

De mesma forma, a concepção da existência de direitos reprodutivos e sexuais ocorreu durante a Conferência Mundial sobre a

\footnotetext{
${ }^{4}$ UNITED NATIONS. Report of the United Nations World Population Conference. Bucharest: United Nations Publications, 19-20 ago. 1974, sales no. E.75, XIII.3. Disponível em: $<$ http://www.un.org/en/development/desa/population/events/conference/index.shtml >. Acesso em: 07 ago. 2018.

${ }^{5}$ DINIZ, Maria Helena. O estado atual do Biodireito. São Paulo: Saraiva, 2002. p. 133.
} 
População e Desenvolvimento, organizada pela ONU, em 1994, na cidade do Cairo. Em tal conferência, destacou-se a redação do Princípio 8:

Toda pessoa tem direito ao gozo do mais alto padrão possível de saúde física e mental. Os Estados devem tomar todas as devidas providências para assegurar, na base da igualdade de homens e mulheres, o acesso universal aos serviços de assistência médica, inclusive os relacionados com saúde reprodutiva, que inclui planejamento familiar e saúde sexual. Programas de assistência à saúde reprodutiva devem prestar a mais ampla variedade de serviços sem qualquer forma de coerção. Todo casal e indivíduo tem o direito básico de decidir livre e responsavelmente sobre o número e o espaçamento de seus filhos e ter informação, educação e meios de o fazer ${ }^{6}$.

\section{Assim, a Plataforma de Ação do Cairo, estabelecida na Conferência Mundial sobre População e desenvolvimento, passa a reconhecer o planejamento familiar como direito atribuído a qualquer pessoa. como informa seu Capítulo VII:}

Os direitos reprodutivos incluem certos direitos internacionais que já estão reconhecidos nas leis nacionais, nos documentos internacionais sobre direitos humanos e em outros documentos pertinentes das Nações Unidas aprovados por consenso. Esses direitos firmam-se no reconhecimento do direito básico de todos os casais e indivíduos a decidir livre e responsavelmente o número de filhos, o espaçamento dos nascimentos e o intervalo entre eles, e a dispor da informação e dos meios para tanto e o direito a alcançar o nível mais elevado de saúde sexual e reprodutiva. A promoção do exercício responsável desses direitos de todos deve ser a base principal das políticas e programas estatais e comunitários na esfera da saúde reprodutiva, incluindo o planejamento familiar ${ }^{7}$.

No Brasil, portanto, após o reconhecimento da força axiológica dos direitos fundamentais, considerados princípios constitucionais, entende-se que estes se encontram carregados de normatividade, obtendo aplicação semelhante à das leis, com força vinculante. Dentre tais direitos, encontra-se incluído o planejamento familiar, constituído no artigo 226, $\S 7^{\circ}$ da Constituição Federal:

6 PATRIOTA, Tania. Relatório da conferência internacional sobre população e desenvolvimentoplataforma de Cairo. 1994. Disponível: 〈http://www.spm.gov.br/Articulacao/articulacaointernacional/relatorio-cairo.pdf >. Acesso em 23 ago. 2018.

${ }^{7}$ Id. Ibid. 
Fundado nos princípios da dignidade da pessoa humana e da paternidade responsável, o planejamento familiar é livre decisão do casal, competindo ao Estado propiciar recursos educacionais e científicos para o exercício desse direito, vedada qualquer forma coercitiva por parte de instituições oficiais ou privadas ${ }^{8}$.

Fica claro, portanto, a natureza de direito fundamental do planejamento familiar, que, conforme estabelecido pela Carta Magna, atribui somente ao casal a responsabilidade da decisão sobre como constituir uma família, incluindo as disposições relacionadas ao controle de natalidade e fecundidade, quantidade de filhos esperada e até mesmo o espaçamento entre uma gestação e outra.

O referido princípio, apesar de ser encontrado na Constituição Federal, é regulamentado na Lei 9.263 de 1996, que determina ser assegurado a todo cidadão, não somente aos casais, o planejamento familiar de maneira livre, não sendo permitido ao Estado, à sociedade ou a qualquer outro particular o estabelecimento de limites ou condições para o seu exercício, dentro do âmbito da autonomia privada do indivíduo ${ }^{9}$. Fica, portanto, definido o planejamento familiar, em seu artigo $2^{\circ}$, como "o conjunto de ações de regulação da fecundidade que garanta direitos iguais de constituição, limitação ou aumento da prole pela mulher, pelo homem e pelo casal" ${ }^{10}$, também defendendo em seu artigo $9^{\circ}$ :

Para o exercício do direito ao planejamento familiar, serão oferecidos todos os métodos e técnicas de concepção e contracepção cientificamente aceitos e que não coloquem em risco a vida e a saúde das pessoas, garantida a liberdade de opção ${ }^{11}$.

No entanto, quando constatada a esterilidade ou infertilidade do casal, este tem o seu planejamento familiar prejudicado, uma vez que são reduzidas as escolhas que podem ser realizadas a respeito de como constituir sua família. Para tanto, as técnicas de reprodução assistida surgem para que os casais com dificuldade reprodutiva ou também os pares

\footnotetext{
${ }^{8}$ BRASIL. Constituição (1988). Constituição da República Federativa do Brasil, Brasília, DF, 5 out 1988. Disponível em: http://www.planalto.gov.br/ccivil_03/constituicao/constituicaocompilado.htm. Acesso em: 26 jul. 2018.

${ }^{9}$ BRASIL. Lei 9.263, de 12 de janeiro de 1996. Regula o $§ 7^{\circ}$ do art. 226 da Constituição Federal, que trata do planejamento familiar, estabelece penalidades e dá outras providências. Câmara dos Deputados, Brasília, DF, 12 jan. 1996. Disponível em: http://www2.camara.leg.br/legin/fed/lei/1996/lei-9263-12-janeiro-1996-374936-normaatualizadapl.html. Acesso em: 26 jul. 2018.

${ }^{10}$ Id. Ibid.

${ }^{11}$ Id. Ibid.
} 
naturalmente impossibilitados de se reproduzir, como os casais homoafetivos, possam satisfazer seu anseio de "constituir uma família".

Tais técnicas de reprodução medicamente assistida encontram-se mencionadas no já referido artigo $226, \S 7^{\circ}$ da Constituição, uma vez que há previsão do provimento, pelo Estado, de "recursos educacionais e científicos" para o exercício do direito ao planejamento familiar ${ }^{12}$. Nesse sentido, Sílvio de Salvo Venosa nota que deve ser comprovada a necessidade, oportunidade e conveniência dos procedimentos de reprodução medicamente assistida, utilizados como último recurso na busca pela fertilidade, após a comprovação de que os demais tratamentos para concepção natural tenham sido frustrados ${ }^{13}$.

Ainda assim, deve-se levar em conta a grande importância da reprodução humana assistida no projeto de vida dos indivíduos, garantindo-lhes livre arbítrio e controle na formação de famílias. Tal pensamento se alinha à definição proporcionada pela Organização Mundial de Saúde (OMS), que determina "saúde" como "o completo estado de bem estar físico, mental e social, e não a simples ausência de doença ou enfermidade" ${ }^{\text {.14 }}$ Em consequência, argumenta Giana Lisa Zanardo Sartori:

[...] em um Estado Constitucional Democrático, no qual a Constituição é chave mestra e contempla os Direitos Humanos com os valores correspondentes legitimados por um processo democrático, é possível afirmar que o Direito à Saúde Reprodutiva, no que diz respeito ao acesso às técnicas de Reprodução Humana Assistida encontra amparo e proteção ${ }^{15}$.

Nesse sentido, já é possível depreender um alinhamento jurisprudencial com relação à defesa do planejamento familiar como direito fundamental, de forma que tem início a tutela da saúde procriativa de modo mais eficaz, como demonstra a decisão do Tribunal de Justiça do Rio Grande do Sul, responsável por condenar o Estado e o município de Porto Alegre a custear o tratamento de reprodução medicamente assistida a uma mulher que sofria de abortamento habitual ${ }^{16}$.

\footnotetext{
${ }^{12}$ BRASIL. Constituição (1988). Constituição da República Federativa do Brasil, Brasília, DF, 5 out 1988. op. cit. nota 5.

${ }^{13}$ VENOSA, Sílvio de Salvo. Direito Civil: Direito de Família. 3. ed. 6. vol. São Paulo: Atlas. 2003. p. 281-282.

14 Conceito operacional adotado conforme Organização Mundial da Saúde. Disponível em: 〈http://new.paho.org/bra/>. Acesso em: 07 ago. 2018.

${ }^{15}$ SARTORI, Giana Lisa Zanardo. Reprodução humana assistida: um direito fundamental? Curitiba: Appris, 2015. p. 111.

${ }^{16}$ BRASIL. Tribunal de Justiça do Rio Grande do Sul $\left(22^{a}\right.$ Câmara Cível). Agravo de Instrumento ${ }^{\circ}$ 70067032938. Agravante: Marli da Silva Souza. Agravados: Município de Cachoeirinha e Estado do
} 


\section{AS TÉCNICAS DE REPRODUÇÃO HUMANA ASSISTIDA}

As técnicas de procriação assistida, portanto, servem à função de auxiliar na dificuldade da reprodução humana, devolvendo ao casal o direito à descendência. Tais técnicas são definidas pelo autor Genival Veloso de França como:

[...] o conjunto de procedimentos no sentido de contribuir na resolução dos problemas da infertilidade humana, facilitando assim o processo de procriação quando outras terapêuticas ou condutas tenham sido ineficazes para a obtenção da gravidez desejada ${ }^{17}$.

Em vista disso, a reprodução humana assistida é, em sua essência, a intervenção humana na procriação natural, objetivando possibilitar que pessoas com problemas de infertilidade ou esterilidade consigam gerar filhos, alcançando a maternidade ou paternidade.

Deve-se ressaltar que, ante a esterilidade ou infertilidade, há a possibilidade de utilização, pelo casal, da adoção, em oposição à reprodução assistida. Todavia, ainda que ambas as opções sejam legítimas e em conformidade com o ordenamento jurídico brasileiro, seus resul tados são diferentes, influenciando na carga emocional e psíquica da relação parental, modificando o vínculo estabelecido entre os familiares. Sobre o tema, manifesta-se Eduardo de Oliveira Leite, ao justificar a procriação artificial em oposição à adoção:

[...] ter meu próprio filho e não a inserção de um estranho no grupo familiar, até prova em contrário, é um direito absoluto que, no presente momento, nenhum legislador do mundo civilizado se arriscou a negar ${ }^{18}$.

Continua Leite, em sua justificativa, afirmando que a adoção "não pode ter o poder de anular o esforço empreendido por um casal estéril, na obtenção de seu próprio filho, nem que seja com patrimônio genético

\footnotetext{
Rio Grande do Sul. Relator: Desembargadora Denise Oliveira Cezar. Rio Grande do Sul, 03 nov. 2015. Disponível em: <https://tj-rs.jusbrasil.com.br/jurisprudencia/253510185/agravo-de-instrumento-ai70067032938-rs/inteiro-teor-253510218\#>. Acesso em: 07 ago. 2018.

${ }^{17}$ FRANÇA, Genival Veloso de. Medicina Legal. 6. e. Rio de Janeiro: Editora Guanabara Koogan, 2001. p. 225.

${ }^{18}$ LEITE, Eduardo de Oliveira. Procriações artificiais e o Direito: aspectos médicos, religiosos, psicológicos éticos e jurídicos. São Paulo: Revista dos Tribunais, 1995. p. 139.
} 
reduzido à metade"19, fazendo alusão à modalidade heteróloga de reprodução assistida.

Os procedimentos de procriação assistida são classificados como homólogos ou heterólogos, mediante a forma de utilização de material genético. A técnica é denominada homóloga ou interconjugal quando os gametas utilizados na fecundação artificial são originários do próprio casal com interesse na procriação ${ }^{20}$, podendo ser notada uma conciliação entre a filiação biológica e a afetiva. No caso de impossibilidade dos indivíduos integrantes do casal produzirem seus próprios gametas, havendo necessidade de se recorrer ao material genético oriundo de doação, o procedimento toma o nome de heterólogo ou supra conjugal ${ }^{21}$. Nesta última hipótese, há ainda a possibilidade de a técnica ser considerada heteróloga total, quando nenhum material genético do casal solicitante é utilizado, sendo tanto o espermatozoide quanto o óvulo provenientes de doação.

Há que se notar a diferenciação entre a inseminação artificial e a fertilização in vitro. Enquanto a primeira é considerada um procedimento mais simples e antigo, a fertilização é uma técnica mais moderna, praticada nos laboratórios de reprodução. A inseminação artificial, portanto, ocorre no interior do útero materno, com a utilização de algum veículo para facilitar o encontro dos espermatozoides capacitados, na cavidade uterina, de modo direto ${ }^{22}$, sendo considerada de complexidade baixa, o que influencia no seu valor. Já na fertilização in vitro, a fecundação é externa ao corpo da mulher, com a posterior implantação do embrião em seu útero, sendo comum a criopreservação de embriões para que sejam posteriormente realizadas outras tentativas de implantação ${ }^{23}$.

Ainda, deve ser considerada a maternidade de substituição como uma outra modalidade de reprodução assistida, na qual uma terceira, que deve ser parente consanguínea de até $4^{\circ}$ grau da mãe que demonstrou

\footnotetext{
${ }^{19}$ Id. Ibid.

${ }^{20}$ Conceitos operacionais compostos conforme RED LATINOAMERICANA DE REPRODUCCIÓN ASISTIDA. Manual de Procedimentos - Laboratório de Reprodução Assistida. Disponível em: < http://www.redlara.com/images/arq/livreto_port_01_2007.pdf $>$. Acesso em: 27 jul. 2018.

${ }^{21}$ Id. Ibid.

${ }^{22}$ Id. Ibid.

${ }^{23}$ Id. Ibid.
} 
interesse no procedimento ${ }^{24}$, disponibiliza seu útero para viabilizar a gestação $^{25}$.

Por conseguinte, as inovações alcançadas pelas técnicas de reprodução assistida permitem, além da resolução dos problemas vinculados à infertilidade, a criação de formações não clássicas de família, como as formadas por mulheres na menopausa, casais homoafetivos, pessoas solteiras ou até mesmo por um pai biológico já falecido. É também graças à medicina reprodutiva que se pode prevenir graves problemas de saúde presentes no embrião, devido à utilização do diagnóstico genético pré-implantacional ${ }^{26}$.

\section{LEGISLAÇÃO BRASILEIRA}

Não se pode afirmar que as inovações no campo da reprodução assistida foram acompanhadas pela legislação brasileira, uma vez que a matéria não se encontra totalmente regulamentada no Brasil. Conforme pode ser observado, a Constituição Federal de $1988^{27}$ não realiza nenhuma abordagem em relação ao tema, enquanto que o Código Civil em vigência o trata em apenas três incisos do artigo $1.597^{28}$, deixando a desejar, em matéria de regulamentação, o tratamento dado ao assunto.

Fica claro que, devido à época de sua promulgação, não seria razoável que a Constituição abordasse com afinco a reprodução assistida e suas consequências jurídicas, já que esta ainda não alcançava a popularidade presenciada no momento atual. Ao mesmo tempo, deve-se asseverar que os detalhamentos das relações entre particulares não podem ser considerados a principal prerrogativa da Carta Maior, que disciplina os aspectos gerais do Estado, buscando a manutenção da ordem jurídica ${ }^{29}$.

\footnotetext{
${ }^{24}$ BRASIL. Resolução CFM $n^{o}$ 2.121/2015. Adota as normas éticas para a utilização das técnicas de reprodução. Diário Oficial da União, Brasília, DF, 24 set. 2015. Seção I, p. 117. Disponível em: $<$ http://www.portalmedico.org.br/resolucoes/cfm/2015/2121_2015.pdf $>$. Acesso em 26 jul. 2018.

${ }^{25}$ Conceitos operacionais compostos conforme RED LATINOAMERICANA DE REPRODUCCIÓN ASISTIDA. Manual de Procedimentos - Laboratório de Reprodução Assistida. op. cit. nota 17.

${ }^{26}$ Testes realizados em laboratório para identificar a presença de doenças hereditárias no embrião.

${ }^{27}$ BRASIL. Constituição (1988). Constituição da República Federativa do Brasil, Brasília, DF, 5 out 1988. op. cit. nota 5.

${ }^{28}$ BRASIL. Lei 10.406, de 10 de janeiro de 2002. Código Civil, Brasília, DF, 10 jan. 2002. Disponível em: <http://www.planalto.gov.br/ccivil_03/Leis/2002/110406.htm>. Acesso em 26 jul. 2018.

${ }^{29}$ FURIAN, Leonardo. A Constituição como ordem jurídica e sua função de estabilidade. Disponível em: <http://www.conteudojuridico.com.br/artigo,a-constituicao-como-ordem-juridica-e-sua-funcaode-estabilidade,49832.html>. Acesso em 13 ago. 2018.
} 
Portanto, como já mencionado, o papel da norma constitucional em relação à reprodução assistida é determinar que seja cumprido o direito fundamental ao planejamento familiar, ficando clara, como sugere Karla Ferreira de Camargo Fischer, a estreita relação entre o conceito de família trazido pela Constituição e a faculdade de se buscar métodos não naturais de concepção para a concretização do projeto parental ${ }^{30}$.

Contudo, em se tratando do Código Civil de $2002^{31}$, deve-se entender que a situação é mais complexa, uma vez que o legislador demonstrou a pretensão de dar início ao ajustamento do ordenamento jurídico frente às novidades científicas presentes na época de sua promulgação, incitando debates sobre matérias que ainda não haviam sido tratadas com maiores precauções no Direito brasileiro. Todavia, quando se fala nos procedimentos de procriação assistida, o tema foi abordado somente no artigo 1.597, incisos III, IV e V do Código, determinando a presunção de filiação das pessoas concebidas a partir da utilização das referidas técnicas ${ }^{32}$ :

Art. 1.597. Presumem-se concebidos na constância do casamento os filhos: [...]

III - havidos por fecundação artificial homóloga, mesmo que falecido o marido;

IV - havidos, a qualquer tempo, quando se tratar de embriões excedentários, decorrentes de concepção artificial homóloga;

$\mathrm{V}$ - havidos por inseminação artificial heteróloga, desde que tenha prévia autorização do marido ${ }^{33}$.

Ainda que a decisão do legislador em se manter parcialmente omisso a respeito da reprodução assistida, deve-se entender, como justificativa de sua escolha, a necessidade de uma legislação específica, à parte do Código, que forneça uma regulamentação precisa e adequada sobre o tema, como informa Miguel Reale:

A experiência jurídica, como tudo que surge e se desenvolve no mundo histórico, está sujeita a imprevistas alterações que exigem desde logo a atenção do legislador, mas não no sistema de um código, mas sim graças a leis especiais, sobretudo quando estão

\footnotetext{
${ }^{30}$ FISCHER, Karla Ferreira de Camargo. Inseminação artificial post mortem e seus reflexos no direito de família $e$ no direito sucessório. Disponível em: 〈http://www.ibdfam.org.br/img/congressos/anais/224.pdf >. Acesso em: 06 ago. 2018.

${ }^{31}$ BRASIL. Lei 10.406, de 10 de janeiro de 2002. Código Civil, Brasília, DF, 10 jan. 2002. op. cit. nota 25.

${ }^{32}$ Id. Ibid.

${ }^{33}$ BRASIL. Lei 10.406, de 10 de janeiro de 2002. Código Civil, Brasília, DF, 10 jan. 2002. op. cit. nota 25 .
} 
envolvidas tanto questões de direito quanto de ciência médica, de engenharia genética etc. exigindo medidas prudentes de caráter administrativo, tal como se dá, por exemplo, no caso da fecundação in vitro. Em todos os países desenvolvidos, tais fatos são disciplinados por uma legislação autônoma e específica, inclusive nos Estados Unidos da América e na Inglaterra, nações por sinal desprovidas de Código Civil [...]. Como se vê, a atualidade da nova codificação brasileira não pode ser negada com base em realizações científicas supervenientes, que por sua complexidade, extrapolam do campo do Direito Civil, envolvendo outros ramos do direito, além, repito, de providências de natureza metajurídica ${ }^{34}$.

Como estabelece Reale ${ }^{35}$, resta claro, portanto, o intuito do legislador de não atribuir pormenores ao tema no Código Civil para que fosse evitado o "engessamento" da norma em um campo no qual é difícil prever a existência de inovações e suas consequências jurídicas, devido à quantidade de estudos e pesquisas científicas realizados a seu respeito. Todavia, não se pode deixar de notar que ainda pode ser constatada uma lacuna legislativa em relação à regulamentação das técnicas de reprodução humana assistida no ordenamento jurídico brasileiro, uma vez que tal Lei específica ainda não se encontra promulgada, de forma que Sílvio de Salvo Venosa acrescenta:

advirta-se, de plano, que o Código de 2002 não autoriza nem regulamenta a reprodução assistida, mas apenas constata a existência da problemática e procura dar solução ao aspecto da paternidade. Toda essa matéria, que é cada vez mais ampla e complexa, deve ser regulada por lei específica, por um estatuto ou microssistema ${ }^{36}$.

Consequentemente, abstrai-se que, no momento atual, a Resolução no 2.121 de 2015 do Conselho Federal de Medicina ${ }^{37}$ é o mais próximo que se chega de uma legislação específica para a procriação assistida, visto que a norma trata dos aspectos técnicos a serem seguidos pelos profissionais da saúde e clínicas de fertilização que pretendam oferecer os serviços de reprodução assistida.

\footnotetext{
${ }^{34}$ REALE, Miguel. O novo Código Civil e seus críticos. Revista Jus Navigandi, Teresina, ano 7, n. 54, fev. 2002. Disponível em: 〈https://jus.com.br/artigos/2711/o-novo-codigo-civil-e-seus-criticos〉. Acesso em 06 ago. 2018.

${ }^{35}$ Id. Ibid.

${ }^{36}$ VENOSA, Sílvio de Salvo. Direito Civil: Direito de Família. 5. ed. v. 6. op. cit. nota 10. p. 256.

${ }^{37}$ BRASIL. Resolução CFM n ${ }^{\circ} 2.121 / 2015$. Adota as normas éticas para a utilização das técnicas de reprodução. op. cit. nota 21 .
} 


\section{A RESOLUÇÃO № 2.121/2015 DO CONSELHO FEDERAL DE MEDICINA}

Frisa Eduardo Dantas que, em contraste com a quase inexistência de produção legislativa sobre o tema, as lacunas percebidas no campo da medicina reprodutiva vêm sido preenchidas pelo Conselho Federal de Medicina, com a publicação de suas Resoluções, almejando orientar quais os parâmetros técnicos e éticos adotados quando da utilização das técnicas de reprodução humana assistida ${ }^{38}$. No entanto, não se pode considerar que o Conselho Federal de Medicina seja capaz de deliberar sobre os efeitos jurídicos advindos das relações criadas pela procriação assistida, demonstrando que ainda há a necessidade de uma regulamentação específica.

Não obstante, devem ser ressaltadas as disposições trazidas pela Resolução $n^{\circ} 2.121 / 2015^{39}$, que define como muitos dos procedimentos relacionados à procriação em laboratório devem ocorrer. Sobre a doação compartilhada de gametas, regula o Conselho que deve ser observada a idade limite de 35 anos para as mulheres doadoras, enquanto que para os homens doadores, o limite é de 50 anos de idade ${ }^{40}$. Fica estabelecida, também, a proibição de que um doador, homem ou mulher, seja produtor de mais de duas concepções de crianças de sexos diferentes em uma área de um milhão de habitantes, visando evitar o relacionamento entre pessoas de sexos diferentes com o mesmo genoma, e, consequentemente, a endogamia prejudicial ${ }^{41}$.

Segundo a Resolução, o anonimato dos doadores deve ser obrigatoriamente mantido, com exceção de situações especificadas por motivações médicas, nas quais a identidade do doador poderá ser revelada somente aos profissionais da saúde, conforme o item 4 do Capítulo $\mathrm{IV}^{42}$. Sobre a hipótese, disserta Maria Cláudia Crespo Brauner que podem ser consideradas situações de exceção ao anonimato do doador os casos médicos considerados emergenciais, como quando há necessidade de obtenção de informação genética indispensável à saúde do paciente ou

\footnotetext{
${ }^{38}$ DANTAS, Eduardo. Direito Médico. Rio de Janeiro: Editora GZ, 2012. p. 229-301.

${ }^{39}$ BRASIL. Resolução $C F M n^{o} 2.121 / 2015$. Adota as normas éticas para a utilização das técnicas de reprodução. op. cit. nota 21.

${ }^{40}$ Id. Ibid.

${ }^{41}$ Id. Ibid.

${ }^{42}$ BRASIL. Resolução $C F M n^{\circ} 2.121 / 2015$. Adota as normas éticas para a utilização das técnicas de reprodução. op. cit. nota 21 .
} 
quando comprovada a utilização de gametas com carga genética defeituosa ${ }^{43}$.

Em se tratando da sub-rogação de útero, também conhecida como maternidade de substituição, os itens constantes do Capítulo VII da Resolução determinam que, além da comprovação de impossibilidade de gestar da mãe biológica, as pacientes do procedimento devem apresentar grau de parentesco consanguíneo de até $4^{\circ}$ grau e ser juridicamente capazes $^{44}$. Também fica definida a necessidade de garantia de registro das crianças por seus pais genéticos, providenciada durante a gravidez, bem como a não constatação de cobrança de valores pela mãe hospedeira, para que a prática não se torne comercializável ${ }^{45}$.

Denota-se ocorrer a inseminação artificial post mortem quando o material genético criopreservado do cônjuge ou companheiro já falecido é utilizado para que seja realizada a inseminação, concebendo-se um embrião, portanto, com pai premoriente, de forma que estabelece o referido artigo 1.597, III, do Código Civil, ficando presumido o vínculo de parentesco entre a criança gerada e o de cujus. Em mesmo sentido, estabelece o Enunciado no 106 do Conselho da Justiça Federal do Supremo Tribunal de Justiça:

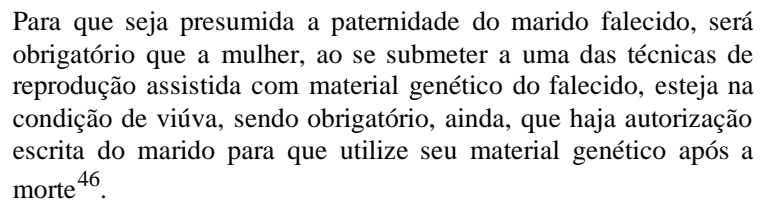

No entanto, por tratar-se de uma questão extremamente delicada, com a concepção de uma criança que viverá sem a figura de seu pai biológico, a prática da reprodução assistida post mortem ainda não é totalmente aceita, uma vez que o ordenamento jurídico brasileiro não a permite expressamente, tampouco veda a sua prática. Sobre o tema,

\footnotetext{
${ }^{43}$ BRAUNER, Maria Cláudia Crespo. Direito, sexualidade e reprodução humana: conquistas médicas e o debate bioético. Rio de Janeiro: Renovar, 2003. p. 88.

${ }^{44}$ BRASIL. Resolução $C F M n^{o} 2.121 / 2015$. Adota as normas éticas para a utilização das técnicas de reprodução. op. cit. nota 21 .

${ }^{45}$ Id. Ibid.

${ }^{46}$ CONSELHO DA JUSTIÇA FEDERAL. Jornadas de direito civil I, III, IV $e$ V: enunciados aprovados. Brasília: Centro de Estudos Judiciários, 2012. p. 28. Disponível em: $<$ http://www.cif.jus.br/cif/corregedoria-da-justica-federal/centro-de-estudos-judiciarios1/publicacoes-1/jornadas-cej/EnunciadosAprovados-Jornadas-1345.pdf>. Acesso em: 07 ago. 2018.
} 
Giselda Maria Fernandes Hironaka opina que, na condição de se fazerem cumpridos os requisitos existentes no referenciado Enunciado do CNJ,

[...] a inseminação post mortem, operar-se-á o vínculo parental de filiação, com todas as consequências daí resultantes, conforme a regra basilar da Constituição Federal, pelo seu art. 226, § $6^{\circ}$, incluindo os direitos sucessórios relativamente à herança do pai falecido ${ }^{47}$.

Quando se fala na existência e delimitação dos direitos dos embriões em situação de criopreservação, também podem ser percebidas divergências ao redor da indagação "seria o embrião, fertilizado in vitro e mantido preservado, pessoa?”. Para tão intrincada questão ainda não há consenso entre os juristas, mas deve-se reparar a recente proposição da Sociedade Americana de Medicina Reprodutiva, que atribui ao embrião preservado a classificação de uma vida em potencial, sendo, portanto, protegido com mais afinco em relação aos demais tecidos derivados do corpo humano ${ }^{48}$. Já sob a ótica civilista, este não pode ser considerado nascituro, porque ainda não foi implantado em útero materno, mas também não pode ser pessoa natural, uma vez que ainda não nasceu. Assim, informa Eduardo Dantas, em uma das possíveis soluções para o dilema, o embrião seria classificado, conforme a definição da Sociedade Americana antes tratada, um ser em potencial, forma precoce da vida humana destinatária de um respeito especial, em uma categoria de proteção jurídica diferente das já existentes, dado que não podem ser considerados pessoas, mas também não são meros tecidos destacados ${ }^{49}$.

\section{CONSIDERAÇÕES FINAIS}

Como pode ser observado, portanto, a reprodução assistida em sua modalidade homóloga, considerada mais simples, não é representante de grandes alterações em relação à forma natural de concepção, posto que o material genético utilizado para sua ocorrência provém do próprio casal

\footnotetext{
47 HIRONAKA, Giselda Maria Fernandes Novaes. As inovações biotecnológicas e o direito das sucessões. Disponível em: 〈http://www.ibdfam.org.br/?artigos\&artigo=290>. Acesso em 21 jul. 2018. ${ }^{48}$ THE ETHICS COMITEE OF THE AMERICAN SOCIETY FOR REPRODUCTIVE MEDICINE. Donating spare embryos for stem cell research. Fertility and Sterility, v. 91, n. 3, mar. 2009. Disponível em: 〈https://www.fertstert.org/article/S0015-0282(08)04779-1/pdf〉. Acesso em: 05 ago. 2018.

${ }^{49}$ DANTAS, Eduardo. Aspectos jurídicos da reprodução humana assistida: comentários à Resolução 2.121/2015 CFM. 1. ed. Rio de Janeiro: Editora GZ, 2017. p. 121-127.
} 
interessado na constituição de uma família. Deve ser observado, contudo, que a anteriormente referida Resolução 2.121 de 2015 e o Código Civil não se mostram eficazes na resolução das contendas jurídicas decorrentes da criopreservação dos óvulos fecundados, como os direitos dos embriões preservados e a sucessão das crianças concebidas através da inseminação artificial post mortem, temas que, até o momento, não encontram dispositivos que os tutelem. A própria Resolução CFM, em exposição de motivos anterior às suas disposições, atesta:

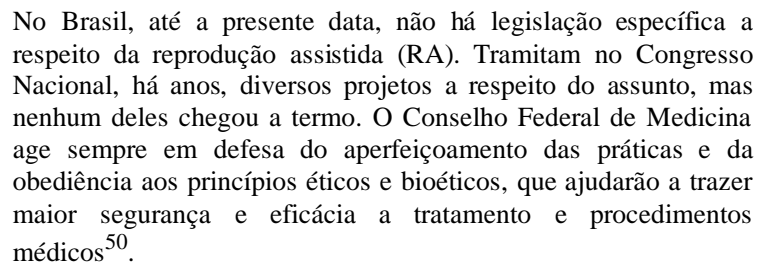

Importante destacar que a situação de ausência de legislação sobre a matéria não é realidade exclusiva do Brasil, mas também de outros Estados. Segundo pesquisa realizada para constatar a existência de legislação e guias de referência regulamentando a reprodução humana assistida, em 103 países investigados, 61 apresentavam diplomas legais insuficientes ou mesmo nenhum dispositivo sobre a prática ${ }^{51}$, sendo a maioria deles, considerados territórios em desenvolvimento, onde, frequentemente, os direitos humanos de seus habitantes são desconsiderados.

Cientes do potencial praticamente ilimitado destas técnicas após o primeiro nascimento decorrente de uma reprodução humana assistida, em

\footnotetext{
${ }^{50}$ BRASIL. Resolução $C F M n^{o} 2.121 / 2015$. Adota as normas éticas para a utilização das técnicas de reprodução. op. cit. nota 158 .

${ }^{51}$ LEITE, Tatiana Henriques; HENRIQUES, Rodrigo Arruda de Holanda. Bioética em reprodução humana assistida: influência dos fatores socioeconômicos-culturais sobre a formulação das legislações e guias de referência no Brasil e em outras nações. Disponível em: $<$ http://www.scielo.br/pdf/physis/v24n1/0103-7331-physis-24-01-00031.pdf >. Acesso em: 06 ago. 2018.
} 
$1978^{52}$, países como Espanha, Portugal ${ }^{53}$, Itália ${ }^{54}$ e Reino Unido ${ }^{55}$ reconhecem a necessidade e utilidade de um diploma próprio com o fim de regular seu uso e aplicação, permitindo os procedimentos que consideram benéficos aos pacientes e proibindo aqueles tomados como não condizentes com a ética médica.

Em retorno à realidade brasileira, depreende-se como resultado da inexistência de legislação específica para a reprodução assistida a existência de uma prática sem controle jurídico específico, demonstrando haver um descompasso entre a legislação mínima vigente e os desdobramentos recorrentes das diversas possibilidades de utilização dos procedimentos de reprodução assistida. Evidentemente, a procriação em laboratório permite a realização completa do projeto familiar desejado por aqueles que se encontram impedidos de constituir uma família, como os casais estéreis e inférteis ou em relacionamentos homossexuais. Todavia, os mesmos procedimentos que se mostram como alternativa reprodutiva, também são geradores de controvérsias jurídicas com relação ao modo como devem ser praticados e às suas consequências no mundo fático.

Assim, enquanto não se percebe a existência de norma regulamentadora da prática, fica a cargo daqueles que a utilizam apoiar-se nos princípios gerais que circundam a ciência e suas aplicações jurídicas no mundo concreto, denominados Bioética e Biodireito, uma vez que, constatada a primeira oportunidade que o homem teve de modificar a natureza, assumiu-se sua obrigação de administrá-la da melhor forma possível para que fossem evitadas catástrofes.

Nesse sentido, a Bioética é definida com "[...] um estudo sistemático da conduta humana no campo das ciências e da saúde, examinada à luz dos princípios morais. É uma resposta aos avanços tecnológicos e científicos no âmbito da saúde e da vida" ${ }^{56}$. Pode-se também utilizar como definição para a Bioética o argumento de que é a ciência com

\footnotetext{
${ }^{52}$ STEPTOE, C.; Edwards, R.G. Birth after the preimplantation of a human embryo. Lancet, v. 2, 1978. p. 366.

${ }^{53}$ PORTUGAL. Lei $n .^{\circ} 32 / 2006$, de 26 de Julho - Procriação Medicamente Assistida. Disponível em: $<$ http://trabalhosacademicosespmsul.blogspot.com/2013/04/citacoes.html〉. Acesso em: 06 ago. 2018.

${ }^{54}$ ITÁLIA. Legge 19 febbraio 2004, n. 40 - Norme in materia di procreazione medicalmente assistita. Gazzetta Uficialle n. 45. Disponível em: 〈http://www.camera.it/parlam/leggi/040401.htm>. Acesso em: 06 ago. 2018.

${ }^{55}$ UNITED KINGDOM. Human Fertilisation and Embriology Act - An Act to amend the Human Fertilisation and Embryology Act 1990 and the Surrogacy Arrangements Act 1985; to make provision about the persons who in certain circumstances are to be treated in law as the parents of a child; and for connected purposes. Disponível em: 〈https://www.legislation.gov.uk/ukpga/2008/22/contents >. Acesso em: 06 ago. 2018.

${ }^{56}$ REICH WT, editor. Encyclopedia of bioethics. New York: The Free Press, vol. I., 1978. p. XIX.
} 
o propósito de estudar "o comportamento moral do homem em relação às ciências da vida"57, com ânimo de impedir o desenvolvimento de uma ciência tecnológica ilimitada, distante da ética e da moral. Dessa forma, demonstram ser pertinentes os ensinamentos de Eduardo de Oliveira Leite sobre o assunto:

Não resta dúvida que foi o desenvolvimento explosivo das ciências tecnológicas no campo biomédico que forçou a renovação da reflexão ética e das problemáticas daí oriundas. Médicos e juristas, filósofos e assistentes sociais foram compelidos a sentar juntos para discutir uma possível tomada de decisão. Não mais, porém, uma decisão individual ou restrita a um setor de indagação científica, mas, ao contrário, uma decisão suficientemente ampla, capaz de, na sua interdisciplinaridade, apresentar uma solução a toda condição humana. [...] o desenvolvimento de novas tecnologias ao serviço da vida ou da saúde colocou em xeque as referências e medidas habituais e os fundamentos da moral e da deontologia que figuravam nos códigos jurídicos que regulavam a conduta humana $^{58}$.

De forma semelhante, pronuncia-se Luiz Edson Fachin, argumentando sobre a dificuldade de se obter respostas exatas, através de nosso ordenamento jurídico, sobre questões, como a reprodução assistida, que envolvem grandes avanços tecnológicos:

O tema remete a dimensão jurídica do próprio corpo humano, apto a fixar limites e possibilidade do sujeito do corpo e do corpo como objeto do direito. [...] Daí o sentido da bioética, princípios necessários para reger condutas aplicáveis à reprodução humana. Diretivas a partir de um "patrimônio comum de valores". Enfrentase aí problema que se refere às fronteiras da ciência e aos eventuais limites éticos, morais ou jurídicos ao desenfreado "progresso científico". [...] Mais do que apontar tal contexto, cabe também perguntar "a que" e "a quem" serve a biotecnologia. Não sem razão, é necessário um olhar crítico sobre o nosso tempo, penetrante e desconfiado desse determinisme lâche que governa a nouvelle vague da economia. Isso tudo para que no corpo do direito não ingresse simplesmente um novo estatuto do corpo humano a título de artefatos da mercantilização, objetos de mercancia suscetível de trânsito na arena jurídica. Não há neutralidade na ética nem na biotecnologia, governada, de um lado, pela lógica do conhecimento

${ }^{57}$ CONTI, Matilde Carone Slaibi. Biodireito: a norma da vida. Rio de Janeiro: Forense, 2004. p. 5.

${ }^{58}$ LEITE, Eduardo de Oliveira. O direito, a ciência e as leis bioéticas. In: SANTOS, Maria Celeste Cordeiro Leite (org.). Biodireito: ciência da vida, os novos desafios. São Paulo: Revista dos Tribunais, 2001. p. 194. 
e do poder, a qual está seguramente associada à lógica do lucro; de outra parte, a lógica do desejo e da livre busca da felicidade ${ }^{59}$.

Concluindo, definida como centro de realização do indivíduo pela Constituição Federal brasileira ${ }^{60}$, a família tem a possibilidade de constituição através dos métodos não naturais de concepção para que seja consolidado o projeto parental. É levando em consideração esta concepção eudemonista de família ${ }^{61}$ que se permite a prática das novidades na área de reprodução humana assistida, sempre de forma a realizar o princípio da dignidade da pessoa humana e os limites atribuídos pela Bioética. Tornase necessário, por consequência, entender que, da mesma forma que preceitua a Carta Maior ${ }^{62}$, o planejamento familiar deve ser atribuído ao casal, na forma de liberdade de decisão dos aspectos que formarão base para sua família.

Ainda, a partir da não constatação de existência de lei específica que discipline a reprodução medicamente assistida no território brasileiro - o que deixa aqueles que desejam dela se utilizar vulneráveis às divergências jurisprudenciais de tribunais com relação aos efeitos dela resultantes - deve ser aplicado o disposto no artigo $4^{\circ}$ da Lei de Introdução às Normas do Direito Brasileiro, segundo o qual devem os magistrados decidir os conflitos de acordo com a analogia, os costumes e os princípios gerais de direito, quando omissa a lei ${ }^{63}$. Resta, portanto, esperar que atividade jurisdicional seja freada quando levados em consideração o princípio da dignidade da pessoa humana e as questões levantadas pela Bioética, enquanto o Poder Legislativo não se pronuncia sobre o tema. Anuncia Maria Helena Diniz, no entanto, que embora existam opiniões contrárias relativas à aplicação da medicina reprodutiva, não deverá o jurista manter-se inerte diante dessa complicada realidade, também não

\footnotetext{
${ }^{59}$ FACHIN, Luiz Edson. Direito de família: elementos críticos à luz do novo Código Civil brasileiro. 2. ed. Rio de Janeiro: Renovar, 2003. p. 251-252.

${ }^{60}$ BRASIL. Constituição (1988). Constituição da República Federativa do Brasil, Brasília, DF, 5 out 1988. op. cit. nota 5.

${ }^{61}$ TRINDADE, Poliana Carla Castro; PEREIRA, Deborah Marques. Eudemonismo e o estatuto da família no direito brasileiro. Conteúdo Jurídico, 28 fev. 2015. Disponível em: <https://www.conteudojuridico.com.br/pdf/cj052605.pdf〉. Acesso em: 07 ago. 2018.

${ }^{62}$ BRASIL. Constituição (1988). Constituição da República Federativa do Brasil, Brasília, DF, 5 out 1988. op. cit. nota 5.

${ }^{63}$ BRASIL. Decreto-Lei $\mathrm{n}^{\circ} 4.567$, de 4 de setembro de 1942. Lei de Introdução às normas do Direito Brasileiro. Brasília, DF, 4 set. 1942. Disponível em: < http://www.planalto.gov.br/ccivil 03/decretolei/Del4657compilado.htm>. Acesso em: 07 ago.2018.
} 
sendo recomendável a omissão do legislador, que deve regulá-la rigorosamente ${ }^{64}$.

Por fim, deve-se recordar a existência da Resolução CFM n ${ }^{\circ}$ 2.121 de $2015^{65}$, responsável pelo início do trabalho de suprir a omissão legislativa sobre a reprodução assistida, que, vinculando os profissionais da saúde e as clínicas de reprodução medicamente assistida, delimita os aspectos procedimentais e éticos envolvendo os pacientes que desejam se submeter às suas técnicas. Ainda sendo necessário salientar que, na hipótese de uma norma futura que regulamente a questão em discussão, deve o legislador permitir a sua utilização quando restar claro não haver possibilidade de risco posterior para o paciente e para o futuro descendente, ou, se impossível evitá-lo, que esteja em conformidade com os parâmetros da normalidade nos demais tratamentos médicos, devendo sempre prezarse pela completa informação a todos aqueles que pretendem submeter-se às suas práticas. Os cuidados aqui exigidos garantem, portanto, que o ser humano seja sempre fim, e nunca meio de outras atividades.

\section{REFERÊNCIAS BILIOGRÁFICAS}

BRASIL. Constituição (1988). Constituição da República Federativa do Brasil, Brasília, DF, 5 out 1988. Disponível em: http://www.planalto.gov.br/ccivil_03/constituicao/constituicaocompilado.htm. Acesso em: 26 jul. 2018.

Decreto-Lei n ${ }^{\circ} 4.567$, de 4 de setembro de 1942. Lei de Introdução às normas do Direito Brasileiro. Brasília, DF, 4 set. 1942. Disponível em: < http://www.planalto.gov.br/ccivil_03/decreto-lei/Del4657compilado.htm>. Acesso em: 07 ago.2018.

Lei 9.263, de 12 de janeiro de 1996. Regula o $§ 7^{\circ}$ do art. 226 da Constituição Federal, que trata do planejamento familiar, estabelece penalidades e dá outras providências. Câmara dos Deputados, Brasília, DF, 12 jan. 1996. Disponível em: http://www2.camara.leg.br/legin/fed/lei/1996/lei-9263-12-janeiro-1996-374936normaatualizada-pl.html. Acesso em: 26 jul. 2018.

Lei 10.406, de 10 de janeiro de 2002. Código Civil, Brasília, DF, 10 jan. 2002.

Disponível em: < http://www.planalto.gov.br/ccivil_03/Leis/2002/110406.htm>. Acesso em 26 jul. 2018.

\footnotetext{
${ }^{64}$ DINIZ, Maria Helena. Curso de Direito Civil brasileiro: Direito de Família. 20. ed. 5. vol. São Paulo: Saraiva. 2005. p. 478.

${ }^{65}$ BRASIL. Resolução $C F M n^{\circ} 1.358 / 1992$. Adota as normas éticas para a utilização das técnicas de reprodução assistida. op. cit. nota 21 .
} 
Resolução CFM no 2.121/2015. Adota as normas éticas para a utilização das técnicas de reprodução. Diário Oficial da União, Brasília, DF, 24 set. 2015. Seção I, p. 117. Disponível em: $<$ http://www.portalmedico.org.br/resolucoes/cfm/2015/2121_2015.pdf >. Acesso em 26 jul. 2018.

. Tribunal de Justiça do Rio Grande do Sul (22 ${ }^{\mathrm{a}}$ Câmara Cível). Agravo de Instrumento $\mathrm{n}^{\circ}$ 70067032938. Agravante: Marli da Silva Souza. Agravados: Município de Cachoeirinha e Estado do Rio Grande do Sul. Relator: Desembargadora Denise Oliveira Cezar. Rio Grande do Sul, 03 nov. 2015. Disponível em: <https://tj-rs.jusbrasil.com.br/jurisprudencia/253510185/agravo-deinstrumento-ai-70067032938-rs/inteiro-teor-253510218\#>. Acesso em: 07 ago. 2018.

BRAUNER, Maria Cláudia Crespo. Direito, sexualidade e reprodução humana: conquistas médicas e o debate bioético. Rio de Janeiro: Renovar, 2003. p. 88.

CONSELHO DA JUSTIÇA FEDERAL. Jornadas de direito civil I, III, IV e V: enunciados aprovados. Brasília: Centro de Estudos Judiciários, 2012. p. 28. Disponível em: <http://www.cjf.jus.br/cjf/corregedoria-da-justica-federal/centro-de-estudos-judiciarios1/publicacoes-1/jornadas-cej/EnunciadosAprovados-Jornadas-1345.pdf >. Acesso em: 07 ago. 2018.

CONTI, Matilde Carone Slaibi. Biodireito: a norma da vida. Rio de Janeiro: Forense, 2004. p. 5.

DANTAS, Eduardo. Aspectos jurídicos da reprodução humana assistida: comentários à Resolução 2.121/2015 CFM. 1. ed. Rio de Janeiro: Editora GZ, 2017. p. 121-127.

Direito Médico. Rio de Janeiro: Editora GZ, 2012. p. 229-301.

DINIZ, Maria Helena. Curso de Direito Civil brasileiro: Direito de Família. 20. ed. 5. vol. São Paulo: Saraiva. 2005. p. 478.

. O estado atual do Biodireito. São Paulo: Saraiva, 2002. p. 133.

FACHIN, Luiz Edson. Direito de família: elementos críticos à luz do novo Código Civil brasileiro. 2. ed. Rio de Janeiro: Renovar, 2003. p. 251-252.

FISCHER, Karla Ferreira de Camargo. Inseminação artificial post mortem e seus reflexos no direito de família e no direito sucessório. Disponível em:

<http://www.ibdfam.org.br/_img/congressos/anais/224.pdf〉. Acesso em: 06 ago. 2018.

FRANÇA, Genival Veloso de. Medicina Legal. 6. e. Rio de Janeiro: Editora Guanabara Koogan, 2001. p. 225.

FURIAN, Leonardo. A Constituição como ordem jurídica e sua função de estabilidade. Disponível em: <http://www.conteudojuridico.com.br/artigo,a-constituicao-como-ordem-juridica-e-sua-funcaode-estabilidade,49832.html>. Acesso em 13 ago. 2018.

HIRONAKA, Giselda Maria Fernandes Novaes. As inovações biotecnológicas e o direito das sucessões. Disponível em: <http://www.ibdfam.org.br/?artigos\&artigo=290>. Acesso em 21 jul. 2018. 
ITÁLIA. Legge 19 febbraio 2004, n. 40 - Norme in materia di procreazione medicalmente assistita. Gazzetta Uficialle n. 45. Disponível em: <http://www.camera.it/parlam/leggi/040401.htm>. Acesso em: 06 ago. 2018.

LEITE, Eduardo de Oliveira. O direito, a ciência e as leis bioéticas. In: SANTOS, Maria Celeste Cordeiro Leite (org.). Biodireito: ciência da vida, os novos desafios. São Paulo: Revista dos Tribunais, 2001. p. 194.

. Procriações artificiais e o Direito: aspectos médicos, religiosos, psicológicos éticos e jurídicos. São Paulo: Revista dos Tribunais, 1995. p. 139.

LEITE, Tatiana Henriques; HENRIQUES, Rodrigo Arruda de Holanda. Bioética em reprodução humana assistida: influência dos fatores socioeconômicos-culturais sobre a formulação das legislações e guias de referência no Brasil e em outras nações. Disponível em:

$<$ http://www.scielo.br/pdf/physis/v24n1/0103-7331-physis-24-01-00031.pdf>. Acesso em: 06 ago. 2018.

NAÇÕES UNIDAS. Texto integral do Relatório da Conferência Internacional sobre População e Desenvolvimento. Plataforma de Cairo, Egito, 5 a 13 set. 1994, p. 43. Disponível em:

<http://www.unfpa.org.br/Arquivos/relatorio-cairo.pdf>. Acesso em 26 jul. 2018.

ORGANIZAÇÃO MUNDIAL DA SAÚDE. Conceito de saúde. Disponível em: <http://new.paho.org/bra/>. Acesso em: 07 ago. 2018.

PATRIOTA, Tania. Relatório da conferência internacional sobre população e desenvolvimento plataforma de Cairo. 1994. Disponível: <http://www.spm.gov.br/Articulacao/articulacaointernacional/relatorio-cairo.pdf $>$. Acesso em 23 ago. 2018.

PORTUGAL. Lei n. ${ }^{\circ}$ 32/2006, de 26 de Julho - Procriação Medicamente Assistida. Disponível em: <http://trabalhosacademicosespmsul.blogspot.com/2013/04/citacoes.html>. Acesso em: 06 ago. 2018.

REICH WT, editor. Encyclopedia of bioethics. New York: The Free Press, vol. I., 1978. p. XIX.

RED LATINOAMERICANA DE REPRODUCCIÓN ASISTIDA. Manual de Procedimentos Laboratório de Reprodução Assistida. Disponível em:

< http://www.redlara.com/images/arq/livreto_port_01_2007.pdf>. Acesso em: 27 jul. 2018.

REALE, Miguel. O novo Código Civil e seus críticos. Revista Jus Navigandi, Teresina, ano 7, n. 54, fev. 2002. Disponível em: 〈https://jus.com.br/artigos/2711/o-novo-codigo-civil-e-seus-criticos〉. Acesso em 06 ago. 2018.

SARTORI, Giana Lisa Zanardo. Reprodução humana assistida: um direito fundamental? Curitiba: Appris, 2015. p. 111.

STEPTOE, C.; Edwards, R.G. Birth after the preimplantation of a human embryo. Lancet, v. 2, 1978. p. 366.

TRINDADE, Poliana Carla Castro; PEREIRA, Deborah Marques. Eudemonismo e o estatuto da família no direito brasileiro. Conteúdo Jurídico, 28 fev. 2015. Disponível em: <https://www.conteudojuridico.com.br/pdf/cj052605.pdf>. Acesso em: 07 ago. 2018. 
THE ETHICS COMITEE OF THE AMERICAN SOCIETY FOR REPRODUCTIVE MEDICINE. Donating spare embryos for stem cell research. Fertility and Sterility, v. 91, n. 3, mar. 2009.

Disponível em: <https://www.fertstert.org/article/S0015-0282(08)04779-1/pdf〉. Acesso em: 05 ago. 2018.

UNITED KINGDOM. Human Fertilisation and Embriology Act - An Act to amend the Human Fertilisation and Embryology Act 1990 and the Surrogacy Arrangements Act 1985; to make provision about the persons who in certain circumstances are to be treated in law as the parents of a child; and for connected purposes. Disponível em:

<https://www.legislation.gov.uk/ukpga/2008/22/contents>. Acesso em: 06 ago. 2018.

UNITED NATIONS. Report of the United Nations World Population Conference. Bucharest: United Nations Publications, 19-20 ago. 1974, sales no. E.75, XIII.3. Disponível em:

<http://www.un.org/en/development/desa/population/events/conference/index.shtml>. Acesso em: 07 ago. 2018.

VENOSA, Sílvio de Salvo. Direito Civil: Direito de Família. 3. ed. 6. vol. São Paulo: Atlas. 2003. p. 281-282. 